\title{
Mineral Liberation Study in The Huanuni Mine, Bolivia*
}

\author{
by Osvaldo ARCE ${ }^{1}$, Masateru NAMBU ${ }^{2}$ \\ and Katsuto NAKATSUKA ${ }^{3}$
}

[UDC $553.065: 622.766]$

The Huanuni ore deposit in the central part of the eastern Andes is a representative tin vein type ore deposit in Bolivia, The veins consist of cassiterite as a economic mineral, being associated mainly with pyrite, pyrrhotite, quartz, tourmaline and rutile.

In this study, the species, grain sizes, shapes of the grains, types of intergrowth, compositions of grains, etc., of each mineral were characterized to assess the liberation characteristics of the ore. Observation on polished specimens under the microscope, heavy liquid separation, powder X-ray diffraction and chemical analysis by ICP were the techniques used to accomplish the mineral liberation study.

Samples collected from the feed in the Huanuni's beneficiation plant were ground and classified into 6 size fractions from mesh Nos. 2 to 200. Each fraction was then separated according to their densities into 8 ranks from +3.20 $\mathrm{g} / \mathrm{cm}^{3}$ to $-2.05 \mathrm{~g} / \mathrm{cm}^{3}$.

The density spectrum has been distributed into two fraction groups, one of $+3.20 \mathrm{~g} / \mathrm{cm}^{3}$ and the other of -2.90 $\mathrm{g} / \mathrm{cm}^{3}$, with lack of intermediate density fractions between them.

X-ray diffraction and microscope analysis have revealed that the heavy group was characterized by the presence of predominant sulfides-cassiterite, and the light one by predominant quartz. The results were confirmed by the chemical analysis of tin and iron. Detailed particle counting under the microscope indicated that about $70 \%$ of total cassiterite was liberated by grinding the raw ore to sizes of $-100+200$ meshes. However, some "liberated" cassiterite particles, even in the finer fraction $(-150+200)$ still contained inclusions of about $3 \mu \mathrm{m}$ to $15 \mu \mathrm{m}$ of tourmaline, pyrrhotite, pyrite and rutile.

KEY WORDS: Mineral Liberation, Cassiterite, Huanuni Mine, Bolivia.

\section{Introduction}

About four-fifths of the world's tin is at present obtained from alluvial deposits and the remainder from load mining.

In alluvial deposits the ground is worked by hydraulic mining and dredging. In hydraulic mining, the ground is broken by means of a jet of water and the slurry is fed by gravel pump to a concentrator. In dredging, the mud is broken by tumbling with water before it is discharged to the concentrator. On the other hand, in lode mining, the veins are emplaced in rock. They are broken up with explosives and the shattered rock is passed by successive stages of comminution required for beneficiation processes. Since cost of comminution are extensively high, the achievement of optimum liberation is therefore of great importance, and accordingly, great attention should be paid to the subject when ores are investigated from an economic point of view.

The largest field of lode mining is Bolivia where the Huanuni mine, owned by the Corporacion Minera de Bolivia (COMIBOL), is a representative tin deposit. It consists of cassiterite as an economic mineral, being associated with pyrite, pyrrhotite, quartz, tourmaline and rutile. The minerals

* Received January 16, 1990: accepted for publication May 30, 1990

1. Graduate student, Faculty of Engineering, Tohoku University, Japan

2. Assistant, Faculty of Engineering, Tohoku University, Aoba-ku, Sendai 980, Japan

3. Prof., Dr., Faculty of Engineering, Tohoku University, Japan generally are fine, formed under super saturation caused by "boiling" of the ore forming fluid ${ }^{1)}$.

In the present study, parameters as grain sizes, shapes of the grains, types of intergrowths, composition of grains, associations and distributions and amounts of composite minerals were statistically characterized to assess the efficiency on the liberation properties of the ore.

Although ore microscopy was the used technique to investigate the optical properties of composite minerals and to perform the particle counting, the process of heavy separation allowed the evaluation and distribution of particles of cassiterite, which were dispersed before the separation in a great amount of gangue mineral particles, for a subsequent mineral liberation and separation.

Other techniques used in this study were X-ray diffraction and chemical analysis by ICP.

\section{Methods}

The samples used in this study were collected from the ball mill feed in the Huanuni beneficiation plant. Their average particle size was about $10 \mathrm{~mm}$. The samples were quartered and ground with ball mill for about $45 \mathrm{~min}$ by wet method. The mill products were then sieved using mesh Nos. 2, 4, 10, $65,100,150$ and 200 .

The heavy media separation was performed on quartered samples of each sieved fraction using heavy liquids of known densities. The heavy liquids used in this study and their 
Table 1 Liquids used in the heavy media separation

\begin{tabular}{lc}
\hline \multicolumn{1}{c}{ Heavy Liquid } & Density* \\
\hline Tetrabromoethane (acetylene tetrabromide) & 2.85 \\
Diiodomethane (methylene iodide) & 3.20 \\
Ethanol & 0.77 \\
\hline * Densities measured at $20^{\circ} \mathrm{C}$ using picnometer.
\end{tabular}

densities are shown in Table 1. The separating mediums of different density were obtained by mixing the heavy liquids with ethanol.

The optical and texture properties of minerals were investigated under the microscope. X-ray diffraction analysis was used as supplement technique to identify the composite minerals of ore and gangue phases. The overall chemical analysis for the relevant elements was determined by optical emission spectroscopy using an inductively coupled plasma source (ICP) after the powdered samples have been dissolved in aqua regia.

The degree of liberation was determined by systematic particle counting on polished sections from separated fraction particles mounted in resine. The numbers of particles counted for individual minerals were first converted to percentages and then to weight percentages using their specific gravities taken from bibliography ${ }^{2)}$. The grades of tin and iron were calculated from chemical compositions of their host minerals cassiterite and pyrite-pyrrhotite, respectively. Since the general chemical formula of pyrrhotite is not stoichiometric $\left(\mathrm{Fe}_{1-x} \mathrm{~S}\right)$, the value for $x$ was assumed to be $0(x=0)$ in order to estimate the approximate content of iron.

\section{Results}

\section{Particle Size Distribution of Ground Samples}

The particle size distribution of milled products is shown in Fig. 1. As seen in the figure, the cumulative $50 \%$ corresponds to the representative particle size of $0.6 \mathrm{~mm}$ and the maximum particle size is about $10 \mathrm{~mm}$.

\section{Results of Heavy Media Separation}

The density spectrum of ground particles is shown in Fig. 2. In the figure, the density spectrum is mainly separated

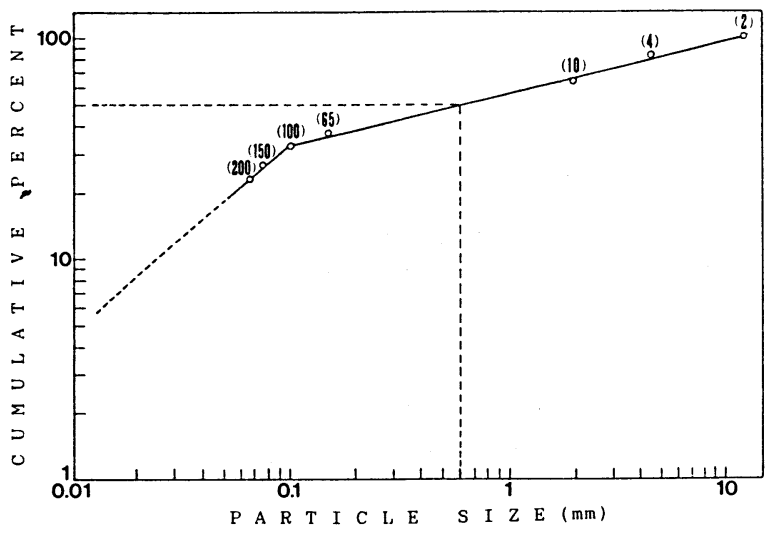

Fig. 1 Particle size distribution of milled products in Log cumulative percent vs. Log particle size $(\mathrm{mm})$. In parentheses are the mesh number. into two distinct density fraction groups, one is +3.20 and the other -2.90 . Those groups are observed more clearly with decreasing of particle size.

It should be mentioned that particles finer than 200 mesh were not separated as far as this study, although they probably show a higher degree of liberation, because of difficulties of circulation accompanied by coagulation of those particles in the liquids used.

\section{Results of X-ray diffraction Analysis}

The results of X-ray diffraction analysis for each of the separated fractions are shown in Table 2. As seen in the table,

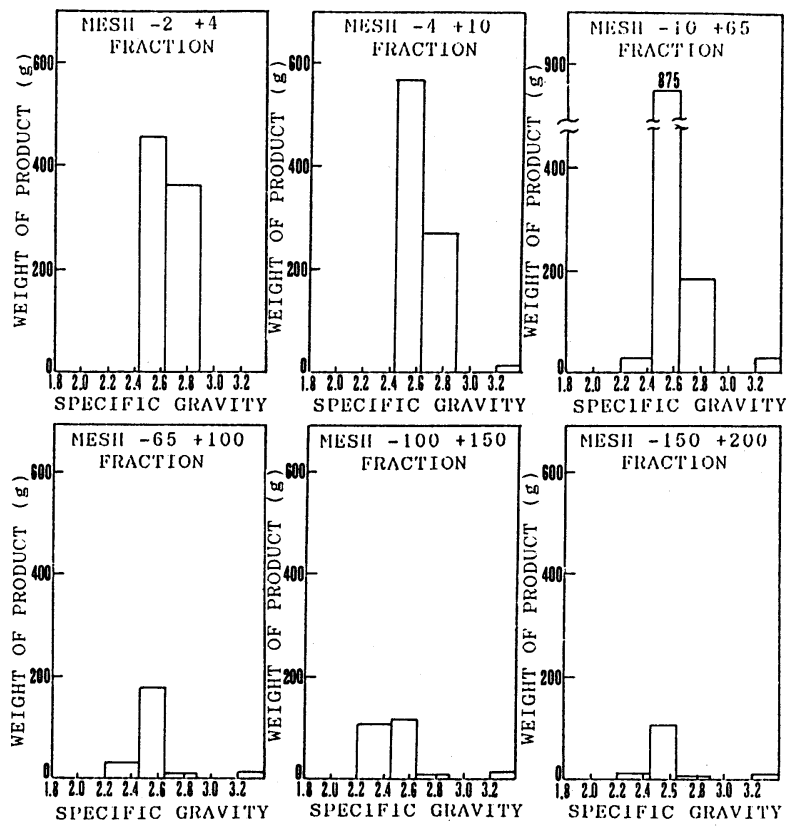

Fig. 2 Distribution of weights of separated fractions as a function of specific gravity.

Table 2 Results of X-ray diffraction analysis of separated fractions.

\begin{tabular}{|c|c|c|c|c|c|c|c|c|c|c|}
\hline \multicolumn{3}{|c|}{ FRACTION } & \multicolumn{8}{|c|}{ MINERALS IDENTIFIED } \\
\hline Mesh No. & Spec. & Grav. & Cs & Py & Po & $\mathrm{Qt}$ & To & $\mathrm{Rt}$ & $\mathrm{Sd}$ & $\mathrm{Cl}$ \\
\hline $\begin{array}{r}2 \\
-\quad+4\end{array}$ & $\begin{array}{l}-2.90 \\
-2.65\end{array}$ & $\begin{array}{l}+2.65 \\
+2.45\end{array}$ & $\mathrm{~m}$ & $\begin{array}{r}m \\
\mathrm{vw}\end{array}$ & & $\begin{array}{r}\mathrm{m} \\
\mathrm{S}\end{array}$ & $\begin{array}{l}\mathrm{m} \\
\mathrm{m}\end{array}$ & $\begin{array}{l}\text { vw } \\
\text { vw }\end{array}$ & vw & $\begin{array}{r}\mathrm{vw} \\
\mathrm{w}\end{array}$ \\
\hline $\begin{array}{r}4 \\
+10\end{array}$ & $\begin{array}{l}+3.20 \\
-2.90 \\
-2.65\end{array}$ & $\begin{array}{l}+2.65 \\
+2.45\end{array}$ & $\begin{array}{l}\mathrm{m} \\
\mathrm{m} \\
\mathrm{w}\end{array}$ & $\underset{\mathrm{m}}{\mathrm{S}}$ & & $\begin{array}{l}\mathrm{m} \\
\mathrm{m} \\
\mathrm{S}\end{array}$ & $\begin{array}{l}\mathrm{m} \\
\mathrm{m} \\
\mathrm{m}\end{array}$ & $\mathrm{vw}$ & w & $\begin{array}{r}\mathrm{vw} \\
\mathrm{w}\end{array}$ \\
\hline $\begin{array}{r}-10 \\
+65\end{array}$ & $\begin{array}{l}+3.20 \\
-2.90 \\
-2.65 \\
-2.45\end{array}$ & $\begin{array}{l}+2.65 \\
+2.45 \\
+2.20\end{array}$ & $\begin{array}{r}\mathrm{m} \\
\mathrm{m} \\
\mathrm{w} \\
\mathrm{vw}\end{array}$ & $\begin{array}{r}\mathrm{S} \\
\mathrm{m} \\
\mathrm{w} \\
\mathrm{vw}\end{array}$ & $\begin{array}{l}\mathrm{w} \\
\mathrm{w}\end{array}$ & $\begin{array}{r}\mathrm{m} \\
\mathrm{S} \\
\mathrm{S} \\
\mathrm{S}\end{array}$ & $\begin{array}{l}\mathrm{m} \\
\mathrm{m} \\
\mathrm{m} \\
\mathrm{m}\end{array}$ & $\begin{array}{l}\text { vw } \\
v w \\
v w\end{array}$ & $\begin{array}{r}\mathrm{w} \\
\mathrm{vw}\end{array}$ & vw \\
\hline $\begin{array}{r}-65 \\
+100\end{array}$ & $\begin{array}{l}+3.20 \\
-2.65 \\
-2.45\end{array}$ & $\begin{array}{l}+2.45 \\
+2.20\end{array}$ & $\begin{array}{r}\mathrm{m} \\
\mathrm{vw}\end{array}$ & $\begin{array}{r}\mathrm{m} \\
\mathrm{vw}\end{array}$ & & $\begin{array}{r}\mathrm{vw} \\
\mathrm{S} \\
\mathrm{S}\end{array}$ & $\begin{array}{c}\mathrm{vw} \\
\mathrm{m} \\
\mathrm{w}\end{array}$ & $\begin{array}{l}\text { vw } \\
\text { vw }\end{array}$ & $\mathrm{vw}$ & vw \\
\hline $\begin{array}{l}-100 \\
+150\end{array}$ & $\begin{array}{l}+3.20 \\
-2.90 \\
-2.65 \\
-2.45\end{array}$ & $\begin{array}{l}+2.65 \\
+2.45 \\
+2.20\end{array}$ & $\begin{array}{l}\mathrm{w} \\
\mathrm{w}\end{array}$ & $\begin{array}{l}\mathrm{m} \\
\mathrm{vw} \\
\mathrm{vw}\end{array}$ & $\mathrm{m}$ & $\begin{array}{c}\mathrm{w} \\
\mathrm{m} \\
\mathrm{S} \\
\mathrm{S}\end{array}$ & $\begin{array}{l}\mathrm{w} \\
\mathrm{m} \\
\mathrm{w} \\
\mathrm{w}\end{array}$ & $\begin{array}{l}\text { vw } \\
\text { vw } \\
\text { vw } \\
\text { vw }\end{array}$ & $\begin{array}{l}\mathrm{vw} \\
\mathrm{vw}\end{array}$ & $\begin{array}{l}\text { vw } \\
\text { vw } \\
\text { vw }\end{array}$ \\
\hline $\begin{array}{l}-150 \\
+200\end{array}$ & $\begin{array}{l}+3.20 \\
-2.90 \\
-2.65 \\
-2.45\end{array}$ & $\begin{array}{l}+2.65 \\
+2.45 \\
+2.20\end{array}$ & $\begin{array}{l}w \\
v w \\
v w\end{array}$ & $\underset{\mathrm{vw}}{\mathrm{m}}$ & $\mathrm{m}$ & $\begin{array}{c}\mathrm{W} \\
\mathrm{m} \\
\mathrm{S} \\
\mathrm{m}\end{array}$ & $\begin{array}{l}\mathrm{m} \\
\mathrm{m} \\
\mathrm{m} \\
\mathrm{m}\end{array}$ & $\begin{array}{l}\text { vw } \\
\text { vw }\end{array}$ & vw & $\begin{array}{l}\text { w } \\
\text { w }\end{array}$ \\
\hline
\end{tabular}

Explanation: $\mathrm{Cs}=$ cassiterite, $\mathrm{Py}=$ pyrite, $\mathrm{Po}=$ pyrrhotite, $\mathrm{Qt}=$ quartz, To = tourmaline, $\mathrm{Rt}=$ rutile, $\mathrm{Sd}=$ siderite, $\mathrm{Cl}=$ clay, $\mathrm{S}=$ strong $; \mathrm{m}=$ moderate, $\mathrm{w}=$ weak, $\mathrm{vw}=$ very weak. 
cassiterite and pyrite-pyrrhotite are common in fractions of densities +3.20 , whereas rutile, siderite and clay minerals showed relatively weak peaks and did not indicate any tendency of distribution in the separated fractions. In addition to the minerals listed in Table 2, marcasite, sphalerite, stannite and chalcopyrite were identified with very weak diffraction peaks.

\section{Chemical Analysis}

In Fig. 3 are shown the weights of tin and iron in each separated fraction as a function of specific gravity. As seen in the figure, both elements were distributed in almost the same densities showing a tendency of distribution.

The grades of tin and iron in each separated fraction are shown in Table 3. As seen in the table, the finer the particle size is, the greater is the ratio between both elements.

Average grades of tin and iron in separated fractions were calculated by dividing the total weights of each element vs. the total weight of the sample:

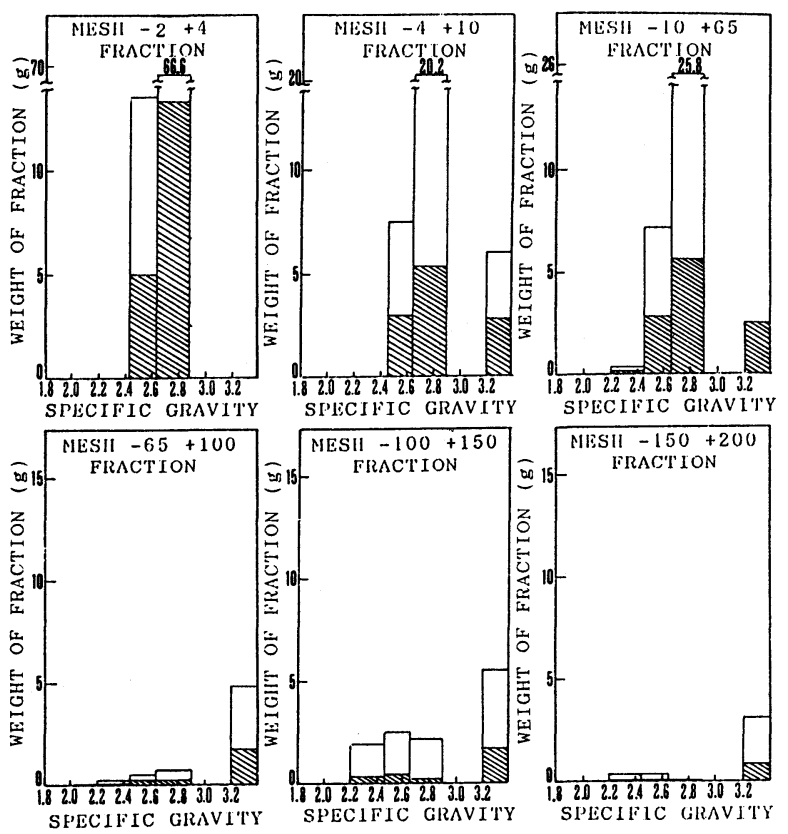

Fig. 3 Distribution of weights of tin and iron as a function of specific gravity. Open data: iron; hatched data: tin. Open data are included in hatched data.

$$
\begin{aligned}
& \text { Sn grade }=\frac{\text { Total weight of } \mathrm{Sn}(\mathrm{g})}{\text { Total sample weight }(\mathrm{g})}=\frac{64.62}{4400}=1.47 \% \\
& \mathrm{Fe} \text { grade }=\frac{\text { Total weight of } \mathrm{Fe}(\mathrm{g})}{\text { Total sample weight }(\mathrm{g})}=\frac{219.67}{4400}=4.99 \%
\end{aligned}
$$

The grades of tin and iron, obtained from direct chemical analysis of bulk samples are:

$$
\begin{aligned}
& \mathrm{Sn}=1.37 \% \\
& \mathrm{Fe}=3.72 \%
\end{aligned}
$$

Although -200 product was not separated by heavy liquids, the chemical analysis for tin and iron in that mesh product indicated grades of $1.72 \%$ for tin and $4.30 \%$ for iron.

\section{Results of Microscopic Analysis}

The detailed mineralogy of the ore in the Huanuni mine has been already reported ${ }^{3)}$. The results of the microscopic analysis on mineralogical characteristics of separated fractions are summarized in Table 4 . The ore phase was mainly composed of cassiterite, pyrite, pyrrhotite, marcasite, stannite, sphalerite and chalcopyrite. The most frequent gangue minerals were quartz, tourmaline, rutile, siderite and clay (Table 4). Sulfides and cassiterite were common in fractions of densities +3.20 , whereas predominant quartz and clay minerals were frequent in fractions of densities -2.90 (Fig. 4).

Since the desired mineral was cassiterite, the particle counting analysis was carried out in separated fractions of densities +3.20 , where cassiterite was mainly concentrated. Because of cassiterite particles coarser than 100 mesh were scarcely liberated (Figs. 4, 5a to $5 \mathrm{~d}$ ) and in order to confirm the reproducibility of the degree of liberation from the first grinding process, samples of $-10+65$ mesh fraction were reground, classified to $-100+150$ and $-150+200$ mesh and then separated to densities +3.20 .

Results of weight percentages of liberated minerals obtained from the analysis of $-100+150$ and $-150+200$ mesh fractions, have indicated that those of cassiterite and nyrite

\begin{tabular}{|c|c|c|c|c|c|c|c|c|c|}
\hline$\frac{\text { SPEC. }}{\text { MES }}$ & $\frac{\text { GRAV. }}{\text { I (No.) }}$ & +3.20 & $\begin{array}{r}-3.20 \\
+3.05\end{array}$ & $\begin{array}{r}-3.05 \\
+2.90\end{array}$ & $\begin{array}{r}-2.90 \\
+2.65\end{array}$ & $\begin{array}{r}-2.65 \\
+2.45\end{array}$ & $\begin{array}{l}-2.45 \\
+2.20\end{array}$ & $\begin{array}{r}-2.20 \\
+2.05\end{array}$ & -2.05 \\
\hline-2 & +4 & $\begin{array}{l}- \\
-\end{array}$ & $\begin{array}{l}- \\
-\end{array}$ & - & $\begin{array}{r}3.71 \\
18.20\end{array}$ & $\begin{array}{l}1.07 \\
3.06\end{array}$ & - & - & $\begin{array}{l}- \\
-\end{array}$ \\
\hline-4 & +10 & $\begin{array}{l}16.81 \\
37.49\end{array}$ & $\begin{array}{l}- \\
-\end{array}$ & - & $\begin{array}{l}1.94 \\
7.30\end{array}$ & $\begin{array}{l}0.55 \\
1.33\end{array}$ & - & - & - \\
\hline-10 & +65 & $\begin{array}{r}7.49 \\
22.98\end{array}$ & $\begin{array}{l}- \\
-\end{array}$ & - & $\begin{array}{r}3.03 \\
13.76\end{array}$ & $\begin{array}{l}0.34 \\
0.87\end{array}$ & $\begin{array}{l}0.98 \\
0.37\end{array}$ & - & - \\
\hline-65 & +100 & $\begin{array}{l}16.20 \\
44.01\end{array}$ & $\begin{array}{l}- \\
-\end{array}$ & $\begin{array}{l}- \\
-\end{array}$ & $\begin{array}{l}2.06 \\
8.37\end{array}$ & $\begin{array}{l}0.13 \\
0.26\end{array}$ & $\begin{array}{l}0.12 \\
0.96\end{array}$ & $\begin{array}{l}0.94 \\
1.36\end{array}$ & - \\
\hline-100 & +150 & $\begin{array}{r}9.94 \\
31.35\end{array}$ & $\begin{array}{l}- \\
-\end{array}$ & - & $\begin{array}{r}1.53 \\
26.20\end{array}$ & $\begin{array}{l}0.32 \\
1.97\end{array}$ & $\begin{array}{l}0.28 \\
1.77\end{array}$ & - & $\begin{array}{l}- \\
-\end{array}$ \\
\hline-150 & +200 & $\begin{array}{r}5.81 \\
20.84\end{array}$ & - & $\begin{array}{l}- \\
-\end{array}$ & $\begin{array}{l}0.10 \\
1.89\end{array}$ & $\begin{array}{l}0.04 \\
0.17\end{array}$ & $\begin{array}{l}0.001 \\
1.32\end{array}$ & - & - \\
\hline
\end{tabular}
decreased considerably, but those of tourmaline increased in the latter mesh fraction with respect to the former one (Tables

Table 3 Distribution of grades for tin and iron in each separated fraction.

Note: The upper values correspond to tin whereas the lower ones to iron. 
Table 4 Mineral characteristics of ore and gangue phases in the feed at the Huanuni mine.

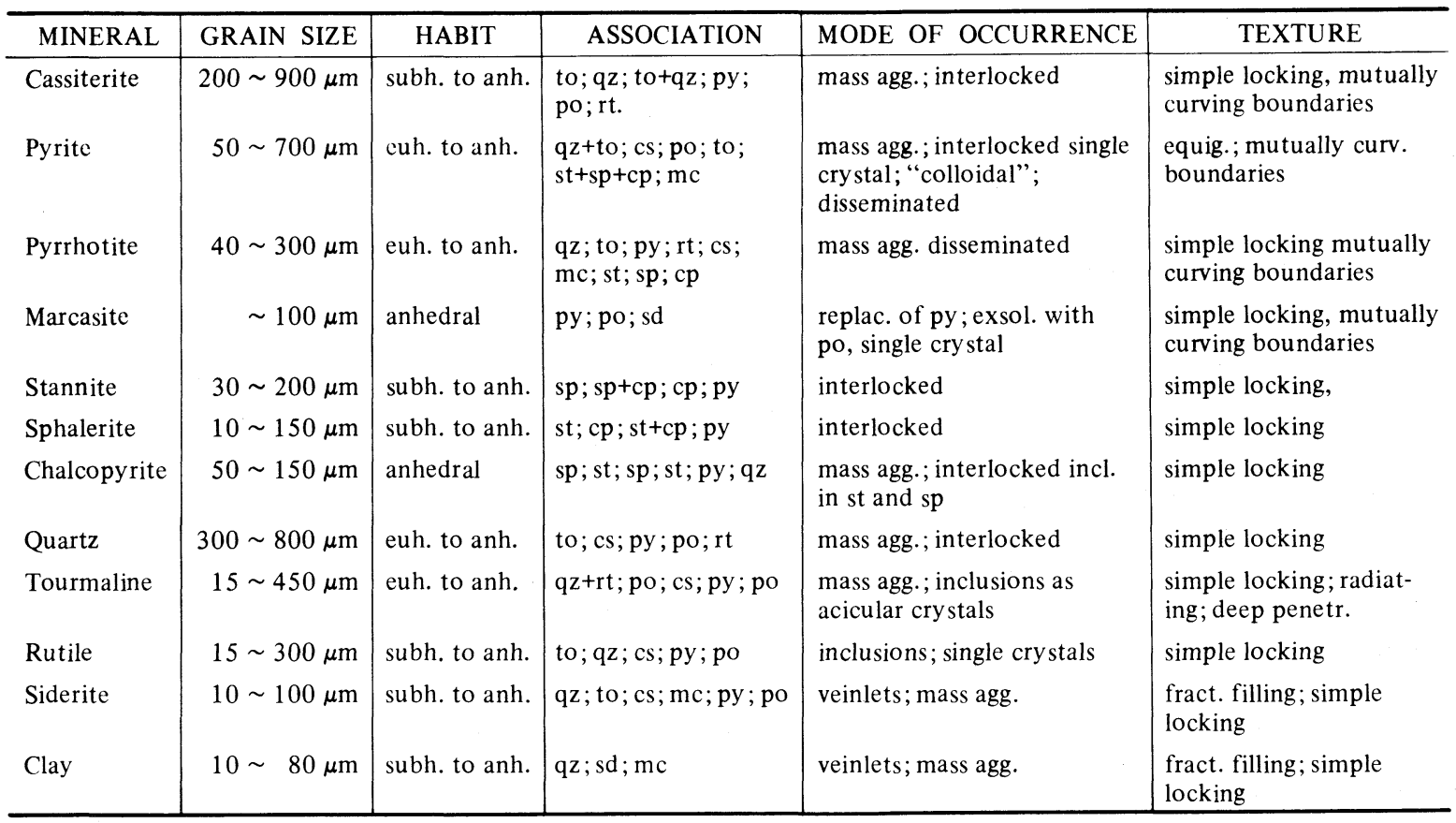

Explanation: euh $=$ euhedral, $\mathrm{subh}=$ subhedral, anh $=$ anhedral, $\mathrm{cs}=$ cassiterite, $\mathrm{py}=$ pyrite, po $=$ pyrrhotite, $\mathrm{qz}=\mathrm{quartz}$, to $=$ tourmaline, $\mathrm{rt}=$ rutile, $\mathrm{st}=$ stannite, $\mathrm{sp}=$ sphalerite, $\mathrm{cp}=$ chalcopyrite, $\mathrm{mc}=$ marcasite, $\mathrm{sd}=$ siderite, $\mathrm{agg}=$ aggregate, replac $=$ replacement, exsol $=$ exsolution, incl $=$ inclusions, equig $=$ equigranular, curv $=$ curving, penetr $=$ penetration, fract $=$ fractures

$\mathbf{5 a}$ and $\mathbf{5 b})$. In both fractions the degrees of liberation of pyrite, pyrrhorite and tourmaline were higher than cassiterite. In Tables $5 \mathrm{a}$ and $5 \mathrm{~b}$ are shown also the grades of tin and iron, which were calculated from chemical compositions of their host minerals.

The most frequent interlocking of minerals are shown in

Table 5c. As seen in the table, unliberated cassiterite was interlocked mainly with tourmaline in fraction sizes -100 +200 mesh.

The liberation degrees of cassiterite were calculated from percentages of free and interlocked particles, obtained in the particle counting analysis (Tables $5 \mathrm{a}$ to $5 \mathrm{c}$ ). Since the liberation of a mineral in ore products can be defined as the percentage of the mineral that is present as free particles ${ }^{4)}$, the liberation degrees of cassiterite in $-100+150$ mesh fraction were $71.81 \%$ and $73.33 \%$ for ground and reground samples respectively. Moreover, cassiterite in $-150+200$ mesh fraction showed liberation degrees of $79.35 \%$ for ground and $71.43 \%$ for reground samples.

\section{Discussion}

The particle size distribution of milled products is shown in Fig.1. As seen in the figure, the size distribution of ground product showed different behavior in Gaudin-Schuhman plot for particles size $-2+100$ mesh and for -100 mesh (Fig. 1) ${ }^{5)}$, because of mixed composition of hard (rocks) and soft (clay) minerals, respectively.

The heavy liquid separation indicated two density fraction groups for particles size $-4+200$ mesh, one was +3.20 and the other -2.90 (Fig. 2). The remainder particle fraction $-2+4$ mesh, which is the coarsest in this study, was separated only in the latter density group, because of the presence of predominant lower density minerals in their interlocked particles.

The densities of the main minerals from separated fractions are: cassiterite $=6.99$, pyrite $=4.7$, pyrrhotite $=4.6$, tourmaline $=3.15$ and quartz $=2.67^{2)}$. As seen in Table 1 , the highest density in the heavy media separation performed in the present study was limited to 3.20 (density of diiodomethane).

$\mathrm{X}$-ray diffraction and microscopic analysis indicated that minerals of +3.20 density fraction were mainly cassiterite and sulfides, whereas separated fractions within densities -2.90 and +2.20 were composed of predominant lower density minerals as quartz and clay (Table 2). The presence of free particles of lower density minerals into higher density fractions e.g. tourmaline in +3.20 fraction was due probably to the coagulation of particles in the heavy liquid ${ }^{6)}$. The lack of fractions within densities -3.20 and +2.90 (Fig. 2) would be explained by the wide differences in densities between those of predominant minerals in both +3.20 and -2.90 fraction groups (Table 2 and Fig. 4). That gap would even be extended as high as the relative density of composite minerals in density +3.20 fraction group, if the density of heavy liquid used would be higher than 3.20. In any case, densities about 3 would be considered as guide condition for the separation of sulfides-cassiterite rich from quartz rich fractions.

The chemical analysis showed that tin and iron are distributed at nearly the same densities in each size fraction. However, both elements are mainly concentrated at densities +3.20 as decreasing the particle size. Therefore, the products separated in density fraction +3.20 will be composed mainly 

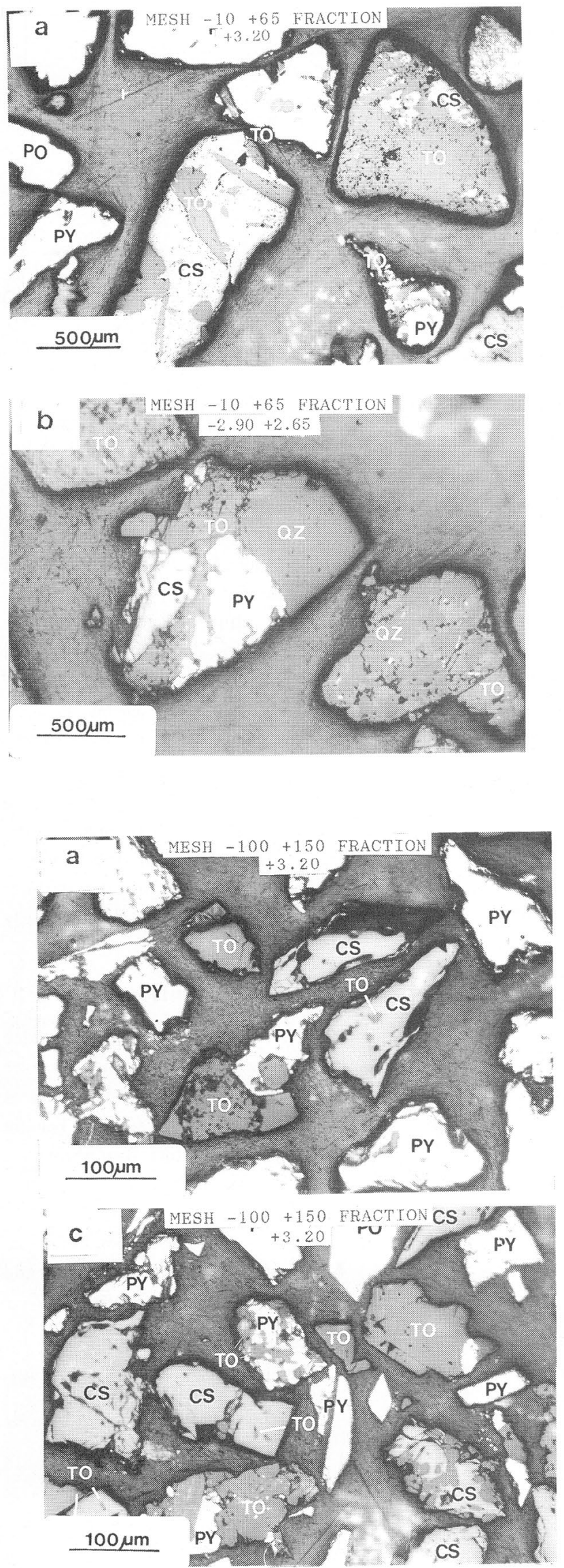

Fig. 5 Microphotographs of mesh $-100+150$ (a and b) and mesh $-150+200$ ( $\mathrm{c}$ and d) fractions for ground (a and c) and

reground (b and d) samples.

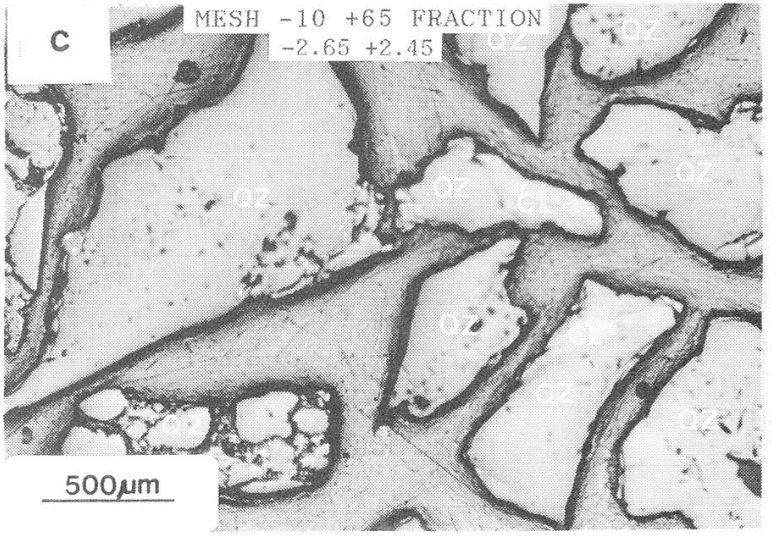

Fig. 4 Microphotographs of mesh $-10+65$ fraction at different densities. Sulfides and cassiterite are common at density +3.20 (a), whereas quartz is predominant at densities lower than 2.90 ( $b$ and $c$ ).

by the host minerals of tin and iron (Tables 2 and 3 ).

The microscopic analysis showed that most of the cassiterite was liberated in particles of sizes finer than 100 mesh (Fig.5). However, some "liberated" cassiterite particles even in the finest fraction of this study $(-150+200$ mesh $)$, still contained inclusions of minerals as tourmaline, pyrrhotite, pyrite and rutile from about $3 \mu \mathrm{m}$ to $15 \mu \mathrm{m}$ in size (Table 4). Since it is not economically practical to carry liberation to completion $^{6)}$, the liberation degree of cassiterite obtained in $-100+200$ mesh fractions (about $70 \%$ ) may be considered
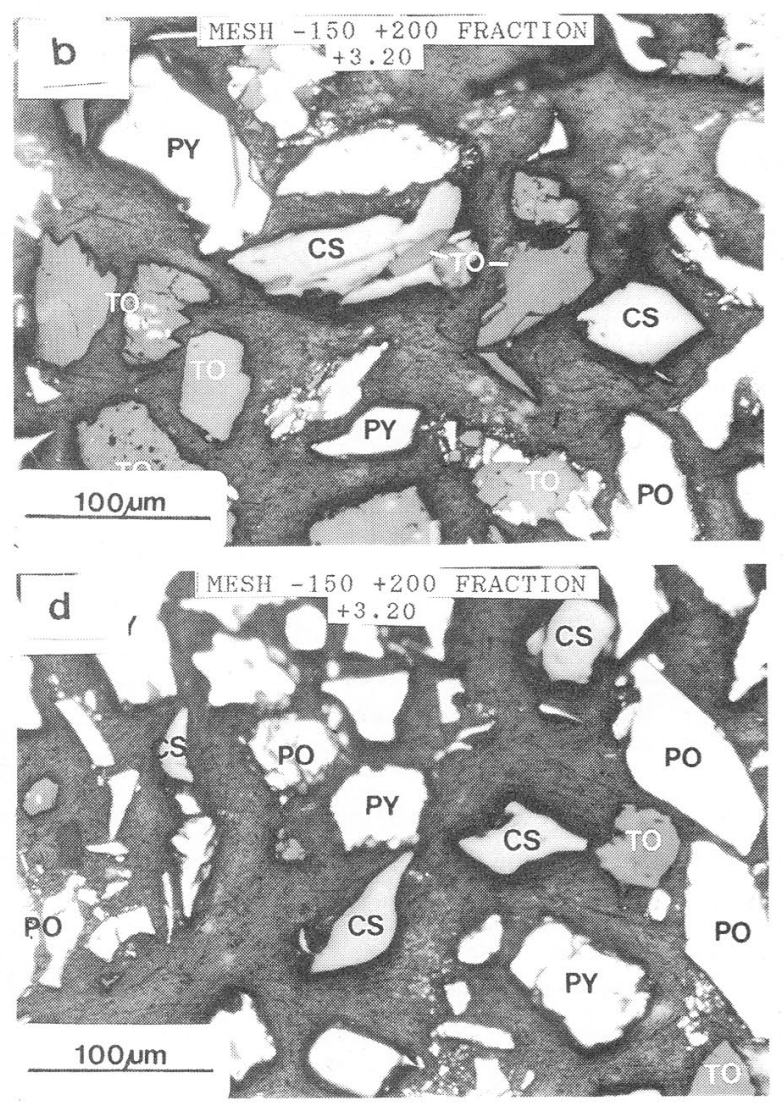
Osvaldo ARCE, Masateru NAMBU and Katsuto NAKATSUKA

Table 5 Results of microscopic particle counting analysis of liberated ( $a$ and $b$ ), and unliberated minerals (c) in mesh $-100+150$ and $-150+200$ fractions, both of densities +3.20 .

a) Liberated minerals in mesh $-100+150$ fraction

\begin{tabular}{|c|c|c|c|c|}
\hline \multirow[t]{2}{*}{ MINERAL } & \multicolumn{2}{|c|}{ GROUND } & \multicolumn{2}{|c|}{ REGROUND } \\
\hline & $\begin{array}{c}\text { LIBERATED } \\
\text { PARTICLES } \\
\% \\
\end{array}$ & $\begin{array}{l}\text { WT. \% LIB. } \\
\text { PARTICLES }\end{array}$ & $\begin{array}{c}\text { LIBERATED } \\
\text { PARTICLES } \\
\%\end{array}$ & $\begin{array}{l}\text { WT. \% LIB. } \\
\text { PARTICLES }\end{array}$ \\
\hline Cassiterite & 9.05 & 13.79 & 10.48 & 15.37 \\
\hline Pyrite & 42.43 & 46.26 & 53.33 & 55.95 \\
\hline Pyrrhotite & 20.98 & 21.04 & 13.33 & 12.87 \\
\hline Stannite & 0.13 & 0.12 & - & - \\
\hline Chalcopyrite & 0.13 & 0.12 & - & - \\
\hline Quartz & 1.07 & 0.62 & 0.96 & 0.53 \\
\hline Tourmaline & 25.47 & 17.49 & 17.14 & 11.33 \\
\hline Siderite & 0.54 & 0.47 & 4.76 & 3.95 \\
\hline Clay & 0.20 & 0.09 & - & - \\
\hline TOTAL & $\overline{100.00}$ & $\overline{100.00}$ & $\overline{100.00}$ & $\overline{100.00}$ \\
\hline No. particles & \multirow{3}{*}{\multicolumn{2}{|c|}{$\begin{array}{c}1492 \\
10.86^{*} ; 9.94 * * \\
34.90^{*} ; 31.35^{* *}\end{array}$}} & \multirow{3}{*}{\multicolumn{2}{|c|}{$\begin{array}{l}105 \\
12.11^{*} \\
33.20^{*}\end{array}$}} \\
\hline Sn grades & & & & \\
\hline Fe grades & & & & \\
\hline
\end{tabular}

b) Liberated minerals in mesh $-150+200$ fraction

\begin{tabular}{l|cc|cc}
\hline \multirow{2}{*}{ MINERAL } & \multicolumn{2}{|c|}{ GROUND } & \multicolumn{2}{c}{ REGROUND } \\
& $\begin{array}{l}\text { LIBERATED WT. \% LIB. } \\
\text { PARTICLES }\end{array}$ & $\begin{array}{c}\text { PARTICLES } \\
\%\end{array}$ & $\begin{array}{c}\text { LIBERATED WT. \% LIB. } \\
\text { PARTICLES }\end{array}$ & PARTICLES \\
\hline Cassiterite & 5.41 & 8.86 & 4.20 & 7.05 \\
Pyrite & 26.15 & 32.37 & 32.77 & 39.32 \\
Pyrrhotite & 15.90 & 18.11 & 17.65 & 19.49 \\
Sphalerite & 0.30 & 0.30 & - & - \\
Chalcopyrite & 0.59 & 0.61 & - & - \\
Quartz & 1.77 & 1.17 & 2.52 & 1.60 \\
Tourmaline & 48.30 & 37.33 & 36.13 & 27.31 \\
Siderite & 0.99 & 0.97 & 3.36 & 3.19 \\
Rutile & 0.59 & 0.28 & 0.84 & 0.85 \\
Clay & - & - & 2.52 & 1.18 \\
TOTAL & 100.00 & 100.00 & 100.00 & 100.00 \\
\hline No. particles & 4050 & & 119 & \\
Sn grades & $6.98 * ; 5.81^{* *}$ & & $5.55^{*}$ & \\
Fe grades & $26.57 * ; 20.84 * *$ & $27.38^{*}$ & \\
\hline
\end{tabular}

c) Mineral interlocking in unliberated particles.

\begin{tabular}{l|cc|cc}
\hline MINERALS & \multicolumn{2}{|c|}{ MESH $-100+150$} & \multicolumn{2}{c}{ MESH -150+200 } \\
& \multicolumn{2}{|c}{ FRACTION } & \multicolumn{2}{c}{ FRACTION } \\
& $\begin{array}{c}\text { GROUND } \\
(\%)\end{array}$ & $\begin{array}{c}\text { REGROUND } \\
(\%)\end{array}$ & $\begin{array}{c}\text { GROUND } \\
(\%)\end{array}$ & $\begin{array}{c}\text { REGROUND } \\
(\%)\end{array}$ \\
\hline Py + To & 28.09 & 33.33 & 25.78 & 41.67 \\
Po + To & 22.47 & 19.05 & 20.00 & 33.33 \\
Cs + To & 16.48 & 19.05 & 12.44 & 20.00 \\
Py + To & 6.74 & 4.76 & 4.44 & - \\
Po + Qz & 5.24 & - & 3.11 & - \\
Cpy+ To & 2.25 & 14.29 & 3.56 & - \\
Cs+Qz+To & 3.37 & - & - & - \\
Others & 15.36 & 9.52 & 30.67 & 5.00 \\
TOTAL & 100.00 & 100.00 & 100.00 & 100.00 \\
\hline No. particles & 267 & 21 & 457 & 12 \\
\hline
\end{tabular}

Note: $*$ and $* *$ : calculated from stoichiometric compositions and from chemical analysis, respectively.

as optimum and metallurgically effective (Fig. 6). The decrease of weight percentage and grade of cassiterite in the size fraction $-150+200$ with respect to $-100+150$ mesh fraction (Tables $3,5 \mathrm{a}$ and $5 \mathrm{~b}$ ), would be explained by the dispersion ${ }^{6)}$ of cassiterite in a lower density minerals, perhaps by coagulation $^{6)}$, in the former fraction with respect to the latter one.

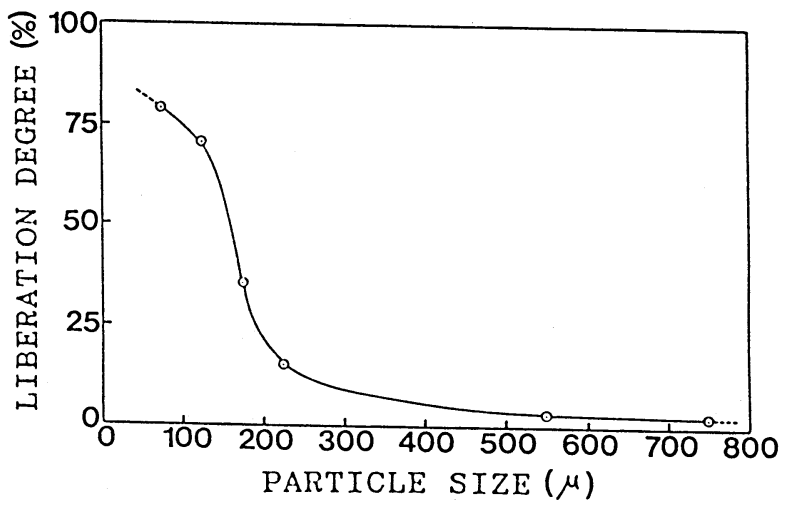

Fig. 6 Liberation degree of cassiterite as a function of particle size.

\section{Conclusions}

The mill in the Huanuni mine is composed of cassiterite as the economic mineral, being associated mainly with pyrite, pyrrhotite, quartz and tourmaline.

The density spectrum showed two distinct fraction groups, one of $+3.20 \mathrm{~g} / \mathrm{cm}^{3}$ and the other of $-2.90 \mathrm{~g} / \mathrm{cm}^{3}$, with lack of intermediate density fractions between them. The heavy group is composed mainly of sulfides-cassiterite, while the light group of quartz and clay. Thus, densities about 3 could be considered as a guide condition for the separation of sulfides-cassiterite rich from quartz rich fractions. Particles lighter than 2.65 could be rejected in the process of beneficiation without any important loss of cassiterite.

Although some cassiterite particles in $-100+200$ mesh fractions still contained inclusions of tourmaline, pyrite, pyrrhotite and rutile ( 3 to $15 \mu \mathrm{m}$ in size), the liberation degree of cassiterite obtained in those fractions, that is about $70 \%$, may be considered as optimum and metallurgically effective.

\section{Acknowledgments}

The authors gratefully acknowledge the support provided by Profs. A. Yazawa and Y. Waseda of the Research Institute of Mineral Dressing and Metallurgy, and Prof. S. Suzuki of the Department of Mining and Mineral Engineering - Tohoku University to this study, which was undertaken through a program of the Group Study Course on Materials, Production and Science at the Tohoku University.

We also thank all the staff of the Corporacion Minera de Bolivia (COMIBOL) for their invaluable cooperation and provision facilities during the field survey.

\section{References}

1) Arce, O. \& Nambu M.: MMIJ journal, No. 14, 105, 47 52, (1989)

2) Dietrich, R.V.: p. 237, (1969), McGraw-Hill Book Co.

3) Arce, O.: Tesis de Grado, Universidad Mayor de San Andres, La Paz, Bolivia, p. 55 (unp.), (1986)

4) Malvik, T.: XIV CIM, Int. Min. Procc. Cong., VIII, $2.1 \sim 2.15$, (1982)

5) Gaudin, A.M.: McGraw-Hill Book Company Inc., (1971)

6) Gaudin, A.M.: McGraw-Hill Book Company Inc., (1957) 


\section{ボリビアHuanuni鉱山鉱石の単体分離に関する研究}

オスバルド アルセ ${ }^{1}$ 南 部 正 光 ${ }^{2}$ 中 塚勝 人 $^{3}$

Huanuni鉱山はボリビアの東部アンデス山地に在り，錫石を稼 行対象とするが, 錫石の他黄鉄鉱, 磁硫鉄鉱, 石英, 電気石, ル チルなどを伴う熱水鉱脈型多金属鉱床である。

本研究の目的は, 釯物の種類, 形状, 共生組織を系統的に明ら かにして, 鉱石の単体分離の特性を評価することである。鉱石の 単体分離を知るために, 顕微鏡観察, 重液分離, 粉末 X線回折, I C Pによる化学分析などを行った。

Huanuni 鉱山の原鈗を粉砕し, $2 \sim 200$ mesh に整粒して, 試料 とした。分級した試料は, 比重 $3.20 \sim 2.05$ 間を 8 等分した重液で 分離した。その結果, 各粒度とも比重 3.20 2.90間の試料が捕集 されず，このギャップを境にして比重の大きいグループと小さい グループとに分かれることが分かった。
$\mathrm{X}$ 線回折および顕微鏡観察によれば比重の大きいグルーブは主 に硫化物一錫石, 小さいグループは主に石英よりなる。 Fe, Snの 化学分析値もこの傾向を支持している。顕微鏡観察の結果, 100 -200meshの粒度では約70\%の錫石が単体分離する。しかし，い わゆる単体分離した細粒側（150２00mesh）の粒子中にも，しば しば数ミクロンの電気石, 磁硫鉄鉱, 黄鉄鉱, ルチルなど包有物 が含まれている。

1. 東北大学研究生 工学部資源工学科

2. 正会員 東北大学助手 工学部資源工学科

3. 正会員 工博 東北大学教授 工学部資源工学科

キーワード : 単体分離, 錫石, ウァヌニ鉱山, ボリビア
E C (欧州共同体)は1992年には市場統合を目指している。その中で，EＣ内 5 力国のベルギー， スペイン，西ドイッ，英国およびフランスの鉱業学会が“EUROM I N ERALS”を設立した。その 詳細は次で述べる。(前号 <8 号 : 会告欄PRESS RELEASE>参照)

\section{EUROMINERALS 一「連合学会の結成 」}

1990 年 6 月 6 日〜 9 日にストラフブルグにおいて開催されたフ ランス鉱業学会においてベルギー, スペイン, ドイッ, フランス および英国など現在の $\mathrm{E} \mathrm{C} \mathrm{メンバー} 5$ 力国の鉱業学会によって欧 州鉱物連合学会 (EUROMI NERALS ) が設立された。

連合学会の会長には英国 I MM会長, DR.BARRY SCOTTが 選ばれ，副会長にはフランス会長のCLAUDE BEAUMONT が 選ばれた。

基本方針

活動範囲は同 5 力国の地域における，鉱物探査，開発および選 鉱, 製鍊ならびに金属処理加工, 工業用材料鉱物, 固形燃料およ び採石等全般にわたる。

新会員の入会には現在の連合学会メンバーの 4 分の 3 の多数決 の投票が必要である。連合学会の拡大にはヨーロッパ地域の非 E C 国も考虑され，その入会には現会員の全会一致を必要とする。 連合学会は各国学会員によって構成され，個人会員は認めない。 各学会は独立性, 自主性を尊重し, いかなる場合も連合学会よ ク各学会に負担をかけるようなことはしない。 各学会が連合学会の主旨に反する場合は会員資格を停止する。 その会員権停止に関する決議は秘密投票により委員会の $3 / 4$ 必要 とする。

\section{連合学会の目的}

その目的は情報の推進に便宜をはかり，情報交換，メンバー間
の相互協力ならびに協同行動をはかる。特にその目的は次の事項 に関連する。

- E C 政府との連絡

一優秀な科学技術に関する評価

一技術に関する会合や会議は各メンバー学会において主催し， 他の会員の代表者や会員の参加をすすめるとともに特に会合 / 会議日程㧍よび議題については適切に調整を行い実施する。 一各学会による定期的または臨時刊行物は適切に行い,できる 限り論文やペーパーの共同出版をする。

\section{連合学会の組織}

連合学会は各国学会より選出された各 3 名の代表者による審議 会 (COU NCIL) によって運営され, 各学会は一票の投票権とす る。審議会はその代表者の中から会長を選出し, その会長は連合 学会の会合を招集する。会長の後継者として副会長を選び, 事務 局を設け，それらの任期はそれぞれ 2 年とする。

審議会は少なくとも年 1 回本部または会長と事務局長の協議に よって決定された場所で行う。特別の審議会は会員による申入書 に従って会長と副会長の同意により実施することができる。

\section{運営瓷金}

連合学会としては当分の間, 最少限の経費によりその目的を遂 行するため, 各国学会においてそれぞれの経費を負担せねばなら ない。

審議会において決定された特定プロジェクトに関連した所要資 金については E C および各国ならびに組織団体の外部より要請す る。

( W ) 